\title{
THERAPY OF LYMPHOGRANULOMA INGUINALE WITH 7218*
}

\author{
BY \\ C. D. ALERGANT \\ Newsham General Hospital, Liverpool
}

The demonstration by Hurst and others (1953) of the effectiveness of quinoxaline-1 : 4-dioxide and certain of its substituted derivatives against lymphogranuloma inguinale in mice and in developing chick embryos led to a request for the trial of one of the most active of these compounds in human lymphogranuloma. The selected compound was $2: 3$ dimethyl quinoxaline-1:4-dioxide (7218).

This paper records our experiences in the administration of 7218 to an unselected series of cases of lymphogranuloma inguinale together with certain observations on the effects of administering the drug to healthy adults.

\section{Material}

The cases of lymphogranuloma inguinale treated with 7218 totalled seventeen (Table I, opposite). All patients admitted to our wards during the period of investigation and diagnosed as suffering from lymphogranuloma inguinale were so treated. All the patients were adult males; six were European and the remainder were Asiatics or Africans of various nationalities. In all cases the infection had been acquired abroad.

All patients were in an early stage of infection, and with one exception presented with inguinal and/or femoral buboes. In eight patients this was unilateral, in the other eight bilateral. In seven patients there was also a palpable enlargement of the deep iliac glands on one or both sides. In the eighth patient inguinal buboes had responded to previous treatment, but he had developed several subcutaneous abscesses of the abdominal wall which had resisted previous chemotherapy. In every case the diagnosis was confirmed by the presence of a lymphogranuloma inguinale complement-fixation test positive in a titre of 1 in $\mathbf{4 0}$ or higher, and in all but two cases by a positive frei skin reaction.

Nine of the seventeen patients had received previous chemotherapy (sulphonamides, aureomycin, penicillin). In no case was treatment with 7218 commenced until it was clear that the patient's condition was stationary or deteriorating.

* Received for publication July 2, 1953.

\section{Dosage and Administration}

The compound was put up in tablets of $250 \mathrm{mg}$. scored down the middle to facilitate division into two halves, and stored in amber-coloured bottles to prevent photodecomposition. Administration was by mouth. The initial scheme of dosage was $125 \mathrm{mg}$. three times daily (total $375 \mathrm{mg}$.) on the first day, $250 \mathrm{mg}$. three times daily (total $750 \mathrm{mg}$.) on the second day, and $375 \mathrm{mg}$. three times daily (total $1,125 \mathrm{mg}$.) on succeeding days. Subsequently, in an attempt to reduce or eliminate toxic side-effects, the maximum daily dose was limited to $750 \mathrm{mg}$. and later to $375 \mathrm{mg}$. Therapeutic effect was evident at all these levels, but no improvement was noted after one week in two patients treated with $150 \mathrm{mg}$. daily. The highest daily dose administered, $1 \cdot 125 \mathrm{~g}$. or $18.75 \mathrm{mg}$. $/ \mathrm{kg}$. body weight, was approximately a third of that found by Hurst and others (1953) to be the optimal dose in experimental mouse lymphogranuloma.*

Length of course and total dosage varied and depended both on therapeutic response and on the presence or absence of toxic side-effects, but in no case was treatment discontinued within less than 7 days. The smallest dose used in a patient whose therapeutic response was considered to be good totalled 6.375 g., whereas the highest total administered was $43 \mathrm{~g}$. The higher dosages were administered as two or more separate "courses" with rest intervals of a week or more between courses.

\section{Clinical Results}

All patients treated with $375 \mathrm{mg}$. or more per day derived some benefit from administration of 7218 , but the degree of improvement varied with individual patients, and although the best results were obtained with the higher dosages, there was nevertheless a lack of uniform response to any given dosage range. Where improvement was marked it occurred in the first 7 to 10 days of treatment and it was found that little was to be gained by prolonging treatment beyond 10 days. In only one case was it felt that a

\footnotetext{
* As dosage for different species is a function of the metabolic rate, the maximum tolerated dose per kilo for man would be much lower than in the mouse.
} 
TABLE I

DOSAGE AND REACTIONS IN SEVENTEEN PATIENTS

\begin{tabular}{|c|c|c|c|c|c|c|c|c|c|c|}
\hline $\begin{array}{l}\text { Case } \\
\text { No. }\end{array}$ & $\begin{array}{c}\text { Uni- } \\
\text { lateral/ } \\
\text { Bi- } \\
\text { lateral }\end{array}$ & $\begin{array}{c}\text { Deep } \\
\text { Iliac } \\
\text { Glands }\end{array}$ & $\begin{array}{c}\text { Frei } \\
\text { Reaction }\end{array}$ & $\mid$\begin{tabular}{c|} 
Lympho- \\
granuloma \\
Inguinale \\
Complement \\
Fixation Test
\end{tabular} & $\begin{array}{l}\text { Previous } \\
\text { Treatment }\end{array}$ & $\begin{array}{c}\text { Total } \\
\text { Dosage } \\
\text { (g.) }\end{array}$ & $\begin{array}{l}\text { Maxi- } \\
\text { mum } \\
\text { Daily } \\
\text { Dose } \\
\text { (g.) }\end{array}$ & $\begin{array}{c}\text { Clinical } \\
\text { Result }\end{array}$ & $\begin{array}{l}\text { Subsequent } \\
\text { Treatment }\end{array}$ & Toxic Reactions \\
\hline 1 & $\mathbf{U}$ & Plus & Pos. & $1 / 160$ & $\begin{array}{l}\text { Aureomycin : } \\
\text { Fever }\end{array}$ & $12 \cdot 5$ & $1 \cdot 125$ & Good & Nil & Muscular cramps \\
\hline 2 & $\mathbf{B}$ & Nil & Pos. & $1 / 160$ & - & 18 & $1 \cdot 125$ & $\begin{array}{c}\text { Fairly } \\
\text { good }\end{array}$ & Aureomycin & Skin reaction \\
\hline 3 & \multicolumn{2}{|c|}{$\begin{array}{l}\text { Abscesses of } \\
\text { abdominal wall }\end{array}$} & Pos. & $1 / 160$ & $\begin{array}{l}\text { Aureomycin } \\
\text { Sulphonamides }\end{array}$ & 9 & $1 \cdot 125$ & $\begin{array}{l}\text { Excel- } \\
\text { lent }\end{array}$ & - & Skin reaction \\
\hline 4 & B & Plus & Pos. & $1 / 160$ & Sulphonamides & 9 & $1 \cdot 125$ & Fair & $\begin{array}{l}\text { Aureomycin } \\
\text { Sulphonamides }\end{array}$ & $\begin{array}{l}\text { Skin reaction. } \\
\text { sional cramp }\end{array}$ \\
\hline 5 & $\mathbf{U}$ & Nil & Pos. & $1 / 320$ & Penicillin & $1 \cdot 7$ & $\cdot 15$ & $\mathrm{Nil}$ & $\begin{array}{l}\text { Aureomycin } \\
\text { Penicillin }\end{array}$ & - \\
\hline 6 & B & Nil & Doubtful & $1 / 80$ & - & $1 \cdot 7$ & $\cdot 15$ & Nil & $\begin{array}{l}\text { Aureomycin } \\
\text { Penicillin }\end{array}$ & - \\
\hline 7 & B & $\mathrm{Nil}$ & Pos. & $1 / 320$ & - & $10 \cdot 5$ & .375 & Fair & $\begin{array}{l}\text { Aureomycin } \\
\text { Sulphonamides }\end{array}$ & 一 \\
\hline 8 & $\mathbf{U}$ & $\mathrm{Nil}$ & Pos. & $1 / 160$ & $\begin{array}{l}\text { Aureomycin } \\
\text { Sulphonamides }\end{array}$ & $7 \cdot 5$ & .375 & Good & - & - \\
\hline 9 & B & Plus & Pos. & 1128 & - & 43 & $1 \cdot 125$ & $\begin{array}{c}\text { Fairly } \\
\text { good }\end{array}$ & $\begin{array}{l}\text { Aureomycin } \\
\text { Sulphonamides }\end{array}$ & Muscular cramps \\
\hline 10 & B & Plus & Pos. & $1 / 64$ & - & $28 \cdot 125$ & $1 \cdot 125$ & Good & - & Mild muscular cramps \\
\hline 11 & $\mathbf{U}$ & Nil & Pos. & $1 / 32$ & - & $7 \cdot 25$ & $1 \cdot 125$ & Good & - & Severe skin reaction \\
\hline 12 & $\mathbf{U}$ & Plus & Doubtful & $1 / 32$ & - & $17 \cdot 9$ & $\cdot 75$ & Fair & Sulphonamides & Skin reaction \\
\hline 13 & B & Nil & Pos. & 1,40 & $\begin{array}{l}\text { Penicillin } \\
\text { Sulphonamides }\end{array}$ & 9 & $\cdot 75$ & Fair & Aureomycin & Skin reaction \\
\hline 14 & $\mathbf{U}$ & Nil & Pos. & $1 / 320$ & - & 7 & $\cdot 75$ & Fair & Sulphonamides & $\begin{array}{l}\text { Skin reaction. Muscular } \\
\text { cramps }\end{array}$ \\
\hline 15 & B & Nil & Pos. & 140 & - & $6 \cdot 375$ & $\cdot 75$ & Good & - & Severe skin reaction \\
\hline 16 & $\mathbf{U}$ & Plus & Pos. & $1 / 320$ & $\begin{array}{l}\text { Aureomycin } \\
\text { Sulphonamides }\end{array}$ & 18 & $1 \cdot 125$ & $\begin{array}{c}\text { Fairly } \\
\text { good }\end{array}$ & - & - \\
\hline 17 & $\mathbf{U}$ & Plus & Pos. & $1 / 40$ & ? Penicillin & $5 \cdot 25$ & $\cdot 375$ & Poor & - & Mild skin reaction \\
\hline
\end{tabular}

second course of treatment had materially improved the clinical result.

In seven patients, clinical improvement was sufficiently striking to enable them to be regarded as clinically cured, judged by the rapid disappearance of pain and tenderness, resolution of peri-adenitis, and residuum of discrete mobile painless glands, normal or a little larger than normal in size, that have been previously described after successful therapy with aureomycin (Alergant, 1950). In other cases, however, clinical improvement stopped short of these desiderata, which were only obtained after the exhibition of aureomycin, sulphathiazole, or both.

The inverse relationship was also seen : patients whose lesions had only partially responded to adequate doses of aureomycin and/or sulphonamides responded satisfactorily to treatment with
7218. Possibly the best results are obtained when two different drugs are exhibited successively.

\section{Toxic Effects}

Two types of toxic reaction were observed : muscle cramps and skin rashes. The former might have been expected at a higher level of dosage as they had been observed in mice when the dosage was sufficiently high (Hurst and others, 1953), but nothing corresponding to the skin rashes had been observed in the experimental animal.

A number of patients complained of cccasional painful cramps in arms and/or legs while receiving 7218. In a few more severe cases, carpo-pedal spasm identical with that seen in cases of tetany was observed. Although patients varied in their liability to develop cramp, there was thought to be a greater tendency to the development of cramp with the 
administration of higher doses than with smaller doses. In no case was it considered necessary to discontinue treatment because of muscular cramps.

Skin reactions, when they occurred, tended to be severe and disabling, and in a number of cases they necessitated the discontinuation of 7218 treatment. Occasionally prodromal itching was noted : in other cases the first symptom was the development of a rash. The essential lesion was an erythroderma affecting the exposed parts. The situations usually affected were the face and neck, a V-shaped area on the front of the chest left uncovered by the opennecked pyjama jacket, and the dorsum of the hands and feet. Oedema was most marked in the loosely attached soft tissues of the face and in severe cases the eyes were completely closed. In addition to the oedema and erythema, vesiculation was present in most cases. The hot, dry, red, and tense skin was very reminiscent of the earlier stages of exfoliative dermatitis.

On discontinuing treatment, recovery occurred in all cases, albeit slowly. Cooling lotions and antihistaminics increased the patients' comfort even if they did not hasten a return to normal.

There appeared to be a complete lack of corelation between dosage and the development of skin reactions. Skin reactions developed in some patients whose maximum daily dosage did not exceed $500 \mathrm{mg}$. and they failed to develop in others whose maximum daily dosage was twice as high. Similarly, whereas some patients tolerated $20 \mathrm{~g}$. or more and did not develop a rash, others developed a rash after receiving as little as $5 \mathrm{~g}$.

In view of the distribution of the rash and its strict limitation to those parts of the body left uncovered, coupled with the known photosensitivity of 7218 , it is tempting to suggest that photosensitization either to $2: 3$ dimethyl quinoxaline-1:4dioxide or to one of its breakdown products played a part in the development of skin reactions. Two factors seem to confirm this suggestion: firstly, whereas severe skin eruptions occurred in a number of European and Chinese patients, they were not seen in either Negroes or dark-skinned Indian patients. ${ }^{*}$ Secondly, it was noted that severe skin eruptions coincided with bright sunny weather. Actually, no rashes were seen between September and March, all occurring between March and September. As the majority of patients were treated in spring and summer this too may be due to coincidence.

Whilst these investigations were in progress and before it became clear that toxic side-effects would

\footnotetext{
* As the Indians formed a much smaller group, it would be unwise to infer too much from this.
}

preclude 7218 from becoming a useful therapeutic agent in the treatment of lymphogranuloma inguinale, it was decided to administer the drug to a group of convalescent patients with no known active disease (Table II). The daily dosage ranged from $500 \mathrm{mg}$. to $1 \cdot 125 \mathrm{~g}$. whilst total dosage ranged from $4.5 \mathrm{~g}$. to $12.4 \mathrm{~g}$. Skin rashes were more frequently seen in this group than amongst the lymphogranuloma patients, possibly because this group was composed entirely of light-skinned Europeans.

TABLE II

REACTIONS IN NINE CONTROLS

\begin{tabular}{|c|c|c|c|}
\hline Case & $\begin{array}{c}\text { Total } \\
\text { Dosage } \\
(\mathrm{g} .)\end{array}$ & $\begin{array}{c}\text { Maximum } \\
\text { Daily } \\
\text { Dosage } \\
\text { (g.) }\end{array}$ & Toxic Reactions \\
\hline $\mathbf{A}$ & 5 & $\cdot 5$ & Mild skin reaction \\
\hline B & 5 & $\cdot 5$ & Mild skin reaction \\
\hline C & $8 \cdot 25$ & $\cdot 75$ & Severe skin reaction. Cramps \\
\hline D & 5 & $\cdot 5$ & Severe skin reaction \\
\hline $\mathbf{E}$ & $11 \cdot 9$ & $\cdot 75$ & Severe muscle cramps \\
\hline $\mathbf{F}$ & $4 \cdot 5$ & $\cdot 5$ & Severe skin reaction \\
\hline $\mathbf{G}$ & $4 \cdot 5$ & .5 & Mild skin reaction. Cramps \\
\hline $\mathbf{H}$ & $12 \cdot 4$ & $1 \cdot 125$ & Severe skin reaction \\
\hline $\mathbf{J}$ & 9 & $1 \cdot 125$ & Nil \\
\hline
\end{tabular}

In these controls, in an endeavour to ascertain whether administration of 7218 in the dosage used produced any changes in the formed elements of the blood, serial estimations of haemoglobin and total and differential white cell counts were made before, during, and after treatment. No significant changes in either haemoglobin levels or in the relative or absolute number of white blood cells were found.

Following the observation that carpo-pedal spasm, clinically identical with that occurring in hypocalcaemic tetany, could occur, serial estimations of serum calcium levels were performed in a number of patients, but in all cases this was shown to be unaltered even in the presence of severe muscle cramp. That the cramps are due to anoxia seems unlikely, since carpo-pedal spasm does not occur even where the circulation of a limb is grossly defective. As cramps are more prone to occur with dosages of $750 \mathrm{mg}$. daily and over, it may be that muscle cramp is dependent on accumulation of 7218 in the blood. A series of blood-level estimations, kindly undertaken by Mr. J. M. Thorp, showed that considerable accumulation of drug could occur at a dosage of $375 \mathrm{mg}$. three times daily, whereas it did not occur with a dosage of $250 \mathrm{mg}$. twice daily 
(Table III). The investigation was, however, concluded without this line of inquiry being further pursued.

TABLE III

BLOOD LEVELS OF 7218 (mg./100 ml.) IN TWO PATIENTS

\begin{tabular}{|c|c|c|c|c|}
\hline \multirow{2}{*}{ Date } & \multirow{2}{*}{ Dose } & \multirow{2}{*}{$\begin{array}{c}\text { Time after } \\
\text { First Dose } \\
\text { (hrs) }\end{array}$} & \multicolumn{2}{|c|}{ Case No. } \\
\hline & & & 11 & 10 \\
\hline $\begin{array}{l}18,4 \sqrt[51]{ } \\
\text { (first day } \\
\text { of dosing). } \\
\text { : }\end{array}$ & $\begin{array}{l}375 \mathrm{mg} .3 \\
\text { times } \\
\text { daily }\end{array}$ & $\begin{array}{l}0 \\
1 \\
2 \\
3 \\
9\end{array}$ & $\begin{array}{l}0 \\
0.69 \\
0.76 \\
0.65 \\
1.17\end{array}$ & $\begin{array}{l}0 \\
0.83 \\
0.83 \\
0.72 \\
1.77\end{array}$ \\
\hline $23 / 4,51$ & & $\begin{array}{l}0 \\
2 \\
9\end{array}$ & $\begin{array}{l}1 \cdot 27 \\
1 \cdot 85 \\
2 \cdot 33^{*}\end{array}$ & $\begin{array}{l}2.56 \\
2.90 \\
2.82 *\end{array}$ \\
\hline 25,451 & $250 \mathrm{mg}$. & $\begin{array}{l}0 \\
2 \\
4 \\
6\end{array}$ & $\begin{array}{l}0.71 \\
1.17 \\
0.95 \\
0.81\end{array}$ & $\begin{array}{l}1 \cdot 80 \\
2 \cdot 11 \\
1.94 \\
1.66\end{array}$ \\
\hline
\end{tabular}

* It is apparent that a considerable accumulation of the drug has occurred during the 5 days of dosing.

\section{Summary and Conclusions}

A clinical trial of $2: 3$ dimethyl quinoxaline-1 :4dioxide in lymphogranuloma is described. Though the drug is therapeutically active, toxic side-effects prevent its being regarded as a useful addition to the pharmacopoeia.

The nature of the side-effects is described and their aetiology discussed.

I am indebted to Dr. E. Weston-Hurst, Biological Department of I.C.I. Ltd., for the supply of 7218 and for much valuable advice, to Mr. J. M. Thorp of I.C.I. Ltd., for the estimations of blood levels of 7218, and to Mr. R. J. Ousby for his help in many matters concerned in the preparation of this paper.

\section{REFERENCES}

Alergant, C. D. (1950). Lancet, 1, 950.

Hurst, E. Weston, Landquist, J. K., Melvin, P., Peters, J. M., Senior, N., Silk, J. A., and Stacey, G. J. (1953). Brit. J. Pharmacol., 8, 297. 